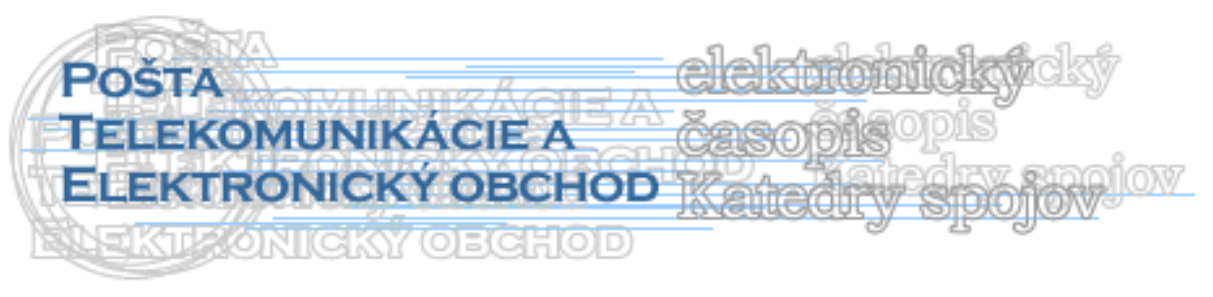

\title{
KVALITA POŠTOVÝCH SLUŽIEB
}

\author{
Karol Achimský ${ }^{1}$
}

Kvalita, v zmysle normy STN EN ISO 9000/2000, je definovaná ako miera s akou súbor vlastných charakteristík spíňa očakávané požiadavky. Táto definícia platí tak pre výrobky ako aj služby. Ako je všeobecne známe na kvalitu výrobku, či služby jestvujú minimálne dva pohl'ady a to zo strany výrobcu, či poskytovatel'a služby alebo spotrebitel'a výrobku, či užívatel'a služby. Pokial' výrobca, či poskytovatel' služby chápe kvalitu ako súhrn vlastností výrobku alebo služby ním stanovenej úrovne a meranie takto vnímanej kvality sa uskutočňuje na základe objektívnych kritérií, spotrebitel', či užívatel' služby chápe kvalitu ako súhrn vlastností výrobku alebo služby ním očakávanej úrovne a meranie takto vnímanej kvality sa uskutočňuje na základe subjektívnych kritérií.

Ked' hovoríme o kvalite ako o miere treba si uvedomit', že každá miera je vlastne zobrazenie

$$
\varphi: \varepsilon \rightarrow R^{+}
$$

kde $\varepsilon$ je „,vhodná štruktúra“ javov, ktoré môžu nastat'.

Z teórie informácie je známe, že v každom prípade sú zabezpečené požiadavky na štruktúru javov ak $\varepsilon$ je $\sigma$-algebra.

Definícia $\varepsilon$ ako $\sigma$-algebry vyžaduje, aby bola uzavretá na zjednotenie a rozdiel a obsahovala celý možný priestor t.j.

$$
\begin{aligned}
& \text { 1) } \quad \forall E, F \in \varepsilon \Rightarrow E \cup F \in \varepsilon, \\
& \text { 2) } \quad \forall E, F \in \varepsilon \Rightarrow E-F \in \varepsilon, \\
& \text { 3) } \quad X \in \varepsilon .
\end{aligned}
$$

Dovolím si ešte pripomenút', že existuje vete, ktorá zjednodušuje overovanie vhodnosti štruktúry, v našom prípade $\sigma$-algebry, ktorá hovorí, že $\varepsilon$ je $\sigma$-algebra, ak je uzavretá na zjednotenie a doplnok t.j.

$$
\begin{aligned}
& \forall E, F \in \varepsilon \Rightarrow E \cup F \in \varepsilon, \\
& \text { 2) } \quad \forall E \in \varepsilon \Rightarrow E^{\prime} \in \varepsilon .
\end{aligned}
$$

Tieto pravidlá by mali byt’ dodržané u rôznych meraní realizovaných akýmkol’vek spôsobom.

\footnotetext{
${ }^{1}$ prof. RNDr. Ing. Karol Achimský, Csc. Katedra spojov, Fakulta prevádzky a ekonomiky dopravy a spojov, Žilinská univerzita v Žiline, Univerzitná 1, 01026 Žilina, Slovenská republika, tel.: +421415133112, fax: +421415655615 e-mail: Karol.Achimsky@fpedas.utc.sk
} 
Samozrejme d'alšou požiadavkou u rôznych meraní, zist'ovaní, či dotazníkových prieskumov je požiadavka na konštrukciu otázky v dotazníku týkajúcej sa nejakého javu. Ideálnym stavom je ak celý priestor javu (všetky možné stavy vytvárajúce vhodnú štruktúru) môžeme rozložit' na konečný počet elementárnych stavov t.j.

2) $\forall E_{i}, E_{j} \in \varepsilon, i \neq j \Rightarrow E_{i} \cap E_{j}=\phi$.

Požiadavku optimálnosti otázky z pohl'adu získavaného maximálneho množstva informácie vyjadruje nasledujúca veta $\mathrm{z}$ teórie informácie:

Entropia (stredné množstvo informácie) je maximálna ak celý priestor otázky (všetky možné stavy v otázke vytvárajúce vhodnú štruktúru) môžeme rozložit’ na konečný počet stavov s rovnakou pravdepodobnost'ou, potom

$$
X=E_{1} \cup E_{2} \cup \ldots \cup E_{n}, p\left(E_{i}\right)=\frac{1}{n} \Rightarrow H(X)=\log n .
$$

Aby som však celkom neotrávil čitatel'ov prejdem $\mathrm{k}$ výsledkom v praxi a vo vhodnom okamihu využijem i uvedenú teóriu.

Možno konštatovat', že tak $\mathrm{v}$ minulosti ako aj $\mathrm{v}$ súčasnosti $\mathrm{v}$ medzinárodnom porovnaní najväčší poskytovatel' poštových služieb v SR Slovenská pošta, ale aj zodpovední za reguláciu a dohl'ad nad kvalitou ponúkaných služieb na trhu, teda MDPT SR a PRÚ, venujú neustálu pozornost' sledovaniu úrovne kvality poskytovaných poštových služieb. Samozrejme, že pozornost' je sústredená najmä na poskytovatel'a univerzálnej služby t.j. SP a.s.

V súčasnosti hodnotenie úrovne kvality poskytovaných služieb u poskytovatel'a univerzálnej služby t.j. SP a.s. je realizované viacerými meraniami a prieskumami. Dovolím si pripomenút' najmä tie, ktoré realizovali pracoviská ŽU ako sú Merania plnenia lehoty prepravy zásielok (listy 1. triedy, listy 2.triedy, balíky a hotovostné poštové platobné poukazy) metódou End to End, Hodnotenie úrovne verbálnej a neverbálnej komunikácie a odbornosti priehradkových zamestnancov metódou Skúšobný zákazník a Meranie indexu spokojnosti zákazníka.

Rozsahom i obsahom, ale i výsledkami uvedených prieskumov sa SP a.s. radí medzi tých národných poštových operátorov na trhu v rámci krajín EU, ktorí patria $\mathrm{k}$ hornej polovici krajín EU z pohl’adu záujmu o kvalitu nimi poskytovaných služieb.

Zároveň badat' zvýšenú snahu o nadviazanie a udržanie vzt’ahu podnikov ponúkajúcich svoje služby so zákazníkom čo je primeranou odpoved'ou na narastajúcu mieru saturácie príslušných trhov služieb.

Ak sa pokúsime porovnat' tieto tri používané metódy $\mathrm{k}$ overovaniu úrovne kvality poskytovaných služieb je nevyhnutné si uvedomovat' určité rozdiely.

Merania plnenia lehoty prepravy zásielok sa venuje výlučne úrovni prepravy od odosielatel'a až po adresáta ako služby poskytovatel'om stanovenej úrovne a meranie takto vnímanej kvality sa uskutočňuje na základe objektívnych kritérií.

Hodnotenie úrovne verbálnej a neverbálnej komunikácie a odbornosti priehradkových zamestnancov metódou Skúšobný zákazník v sebe obsahuje hodnotenie služby poskytovatel'om stanovenej úrovne a meranie takto vnímanej kvality sa uskutočňuje na základe objektívnych kritérií, ale zároveň v sebe obsahuje hodnotenie služby zákazníkom očakávanej úrovne a meranie takto vnímanej kvality sa uskutočňuje na základe 
subjektívnych kritérií. Tento stav lepšie vystihuje názov Kvalifikovaný zákazník ako Skúšobný zákazník.

Meranie indexu spokojnosti zákazníka užívatel' služby chápe kvalitu ako súhrn vlastností výrobku alebo služby ním očakávanej úrovne a meranie takto vnímanej kvality sa uskutočňuje na základe subjektívnych kritérií.

Samozrejme vypovedaciu schopnost' získaných výsledkov okrem objektívnosti, či subjektívnosti kritérií ovplyvňuje významne aj spôsob realizácie.

Pokúsme sa nahliadnut' do výsledkov minulých rokov v hodnotení úrovne verbálnej a neverbálnej komunikácie a odbornosti priehradkových zamestnancov metódou Skúšobný zákazník:

\begin{tabular}{|c|r|r|r|r|r|r|}
\hline Rok & \multicolumn{2}{|c|}{2002} & \multicolumn{2}{c|}{2003} & \multicolumn{2}{c|}{2004} \\
\hline Hodnotené oblasti & Pozitívne & Pozitívne [\%] & Pozitívne & Pozitívne [\%] & Pozitívne & Pozitívne [\%] \\
\hline Očný kontakt & 297 & 99,00 & 578 & 96,33 & 624 & 96,30 \\
\hline Mimika a tón hlasu & 293 & 97,67 & 566 & 94,33 & 616 & 95,06 \\
\hline Pozdrav & 259 & 86,33 & 457 & 76,17 & 498 & 76,85 \\
\hline Odbornost' & 167 & 55,67 & 296 & 49,33 & 327 & 50,46 \\
\hline Tolerancia & 269 & 89,67 & 541 & 90,17 & 619 & 95,52 \\
\hline Počet pozorovaní & 300 & 100,00 & 600 & 100,00 & 648 & 100,00 \\
\hline
\end{tabular}

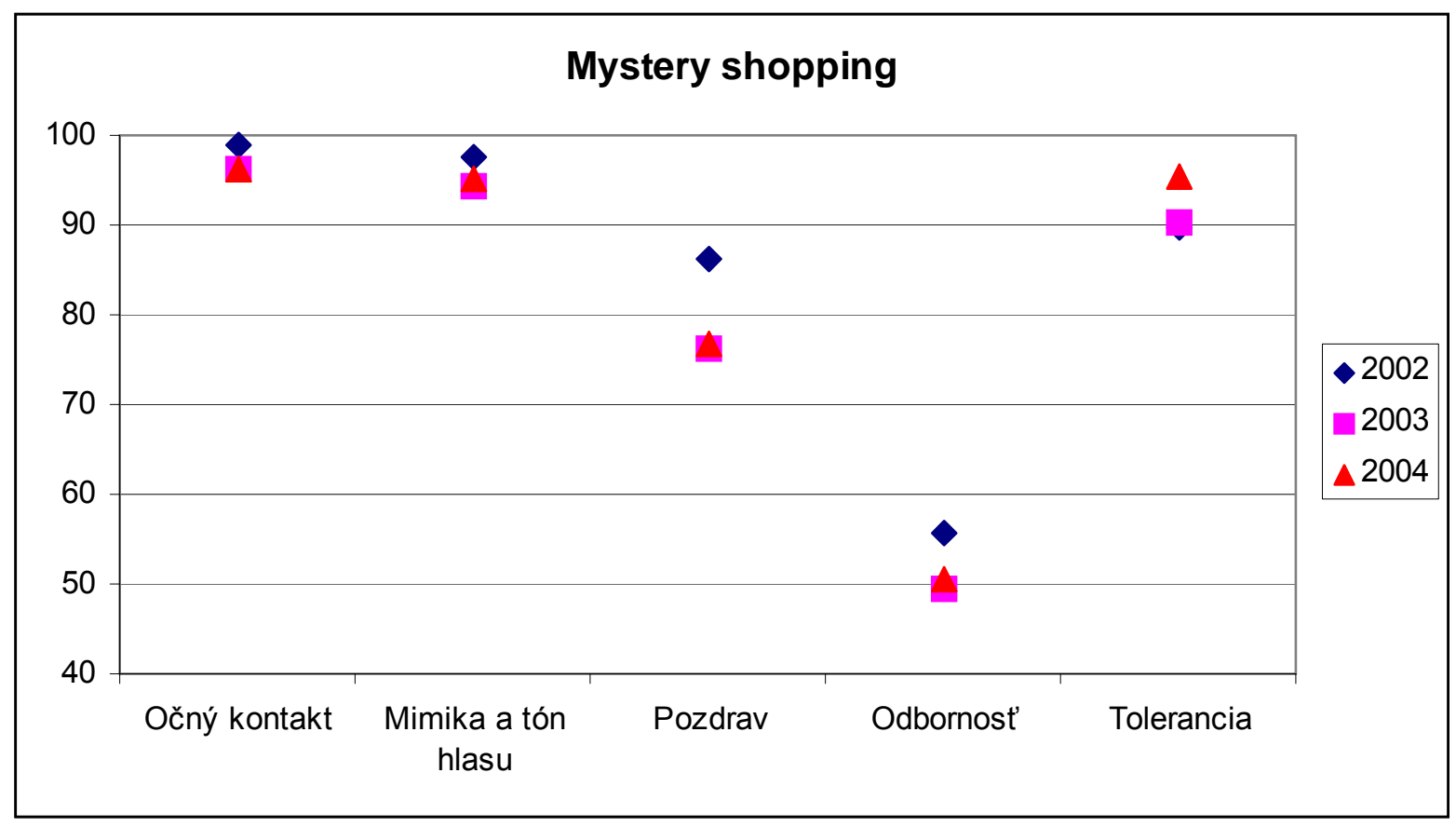

Grafické výsledky posledných troch rokov naznačujú významnú koreláciu u jednotlivých hodnotených prvkov. Zároveň potvrdzujú najvýznamnejšie nedostatky v odbornej príprave priehradkových pracovníkov. Tu však meranie možno považovat' za najobjektívnejšie vzhl'adom na relatívne dobrú meratel'nost' uvedeného prvku.

Výsledky v hodnotení pozdravu sú tiež relatívne objektívne a treba pripomenút', že všetky hodnotené prvky mali len dva možné stavy (vyhovujúci, nevyhovujúci) a u pozdravu sa za vyhovujúci stav považoval aj odzdravenie priehradkového zamestnanca na pozdrav Skúšobného zákazníka.

Zaujímavá je tolerancia a jej vzt’ah k odbornosti, presnejšie povedané následná intolerancia po neodbornosti. 


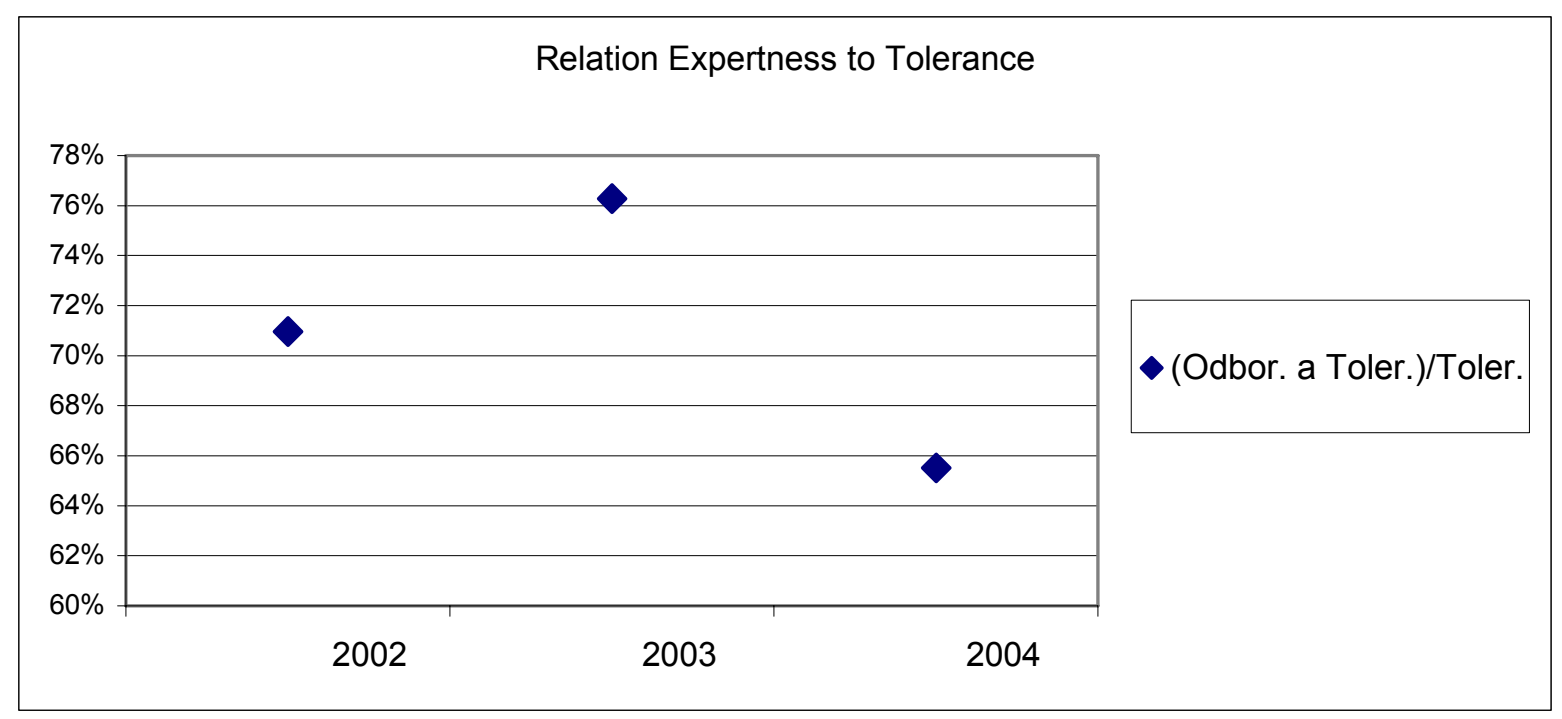

Výsledky ukazujú, že vyskytujúce sa nedostatky v odbornosti nemajú väzbu ani na rozčlenenie poskytovaných poštových služieb na služby Listové, Balíkové, Peňažné a Obstarávatel'ské.

\begin{tabular}{|l|r|r|r|}
\hline \multicolumn{1}{|c|}{ názov/rok } & \multicolumn{1}{c|}{2002} & \multicolumn{1}{c|}{2003} & \multicolumn{1}{c|}{2004} \\
\hline Listová & 50,67 & 48,76 & 40,70 \\
\hline Balíková & 50,70 & 35,67 & 49,47 \\
\hline Peňažná & 57,97 & 51,42 & 50,62 \\
\hline Obstarávatel'ská & 62,35 & 64,25 & 63,28 \\
\hline
\end{tabular}

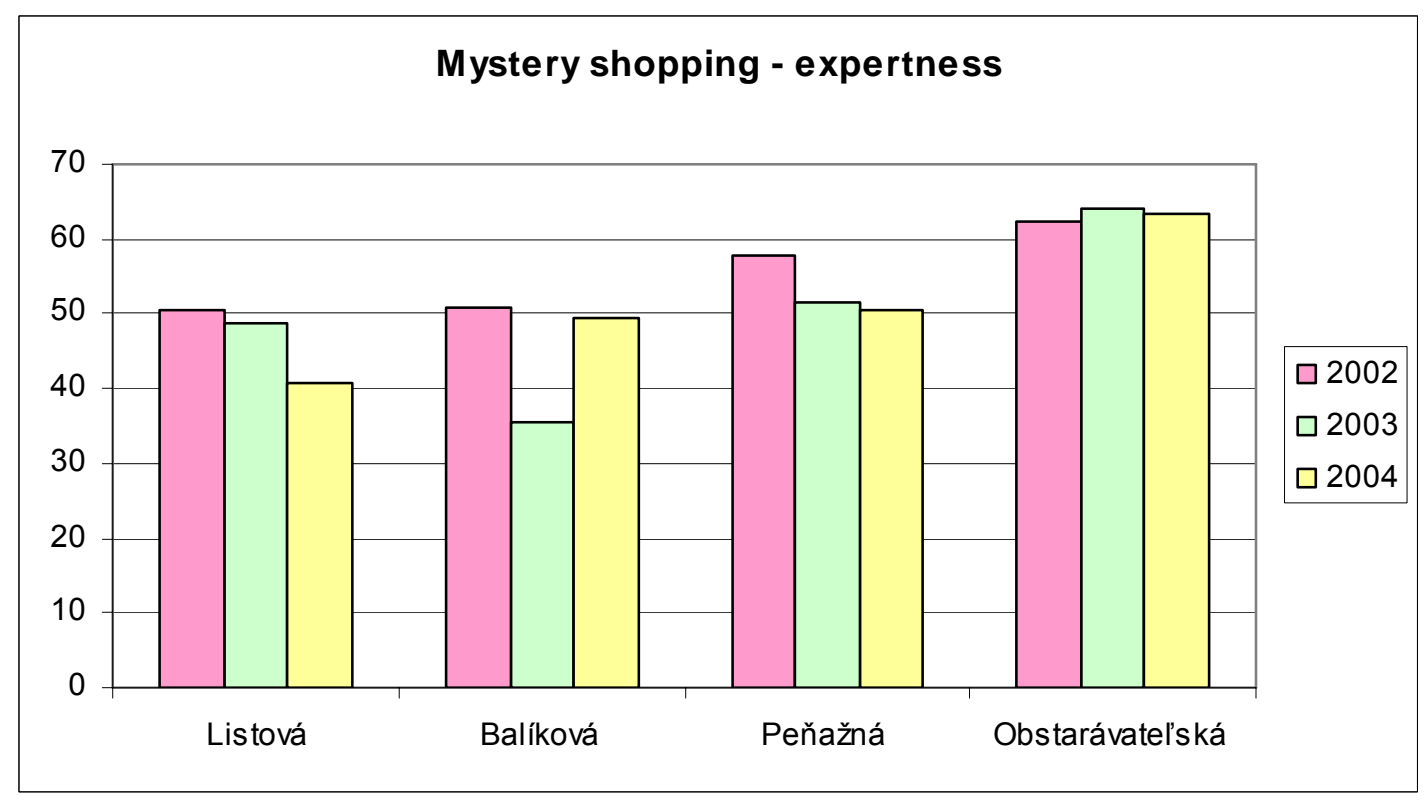

\section{Literatúra:}

[1] Achimský K., Kajánek B., Rostášová M., Kaštánek P., Košt’álová A., Kováčiková M., Kremeňová I., Majerčáková M., Hodáková M., Strenitzerová M., Štofková J., Madleňákova L., Mikušová M., Moravčík M., Vaculík J., Achimská V., Pad'ourová A., Achimská A.,: Skúšobný zákazník, Žilina, r. 2002, 2003, 2004.

Abstract: This article is about quality monitoring of postal services in Slovakia. 